\title{
The Impact of Work Discipline and Work Ethic on the Teacher Performance of Sultan Agung Pematangsiantar Private Middle School Teachers T.A. 2018/2019
}

\author{
Darwin Lie ${ }^{1}$, Sherly ${ }^{2}$, Edy Dharma ${ }^{3}$, Acai Sudirman $^{4 *}$ \\ ${ }^{1,2,3,4}$ Sultan Agung College of Economics, Pematangsiantar 21118, Indonesia
}

\begin{abstract}
A B S T RA C T
This study aims to examine the effect of work discipline and work ethic on the performance of Sultan Agung Private Middle School teachers. The number of samples in this study were 31 teachers obtained by the census method. The instrument used in this study was a questionnaire that was distributed directly to the teacher as a respondent. Testing research instruments using validity and reliability tests. Data analysis used multiple linear regression, correlation, coefficient of demertination, simultaneous and partial test. The results of the research and hypothesis testing show that work discipline variables and the ethic of apes have a positive and significant effect on teacher performance. The empirical findings indicate that in order to improve work discipline at Sultan Agung Pematangsiantar Private Middle School there needs to be a transparent system in recruiting permanent teachers who only teach at Sultan Agung Pematangsiantar Private Middle School so that the teacher focuses on his/her work. Then to improve the work ethic of Sultan Agung Pematangsiantar Private Middle School teachers, the principal as the leader should be able to provide personal and organizational motivation so that every teacher who works can maintain a balance of work ethic competently. Furthermore, to improve performance, every teacher should have the characteristics of self-enhancing potential so that the consistency of teacher professionalism can develop.
\end{abstract}

ARTICLE INFO

Article History:

Received : 30-08-2019

Revised : 22-11-2019

Accepted : 24-11-2019

Published : 28-10-2019

Keywords:

Work Discipline,

Work Ethic,

Teacher Performance

*Corresponding Author E-mail:

acaivenly@stiesultanagung.ac.id

Copyright (c) 2019 Authors. This is an open access article distributed under the Creative Commons Attribution License, which permits unrestricted use, distribution, and reproduction in any medium, provided the original work is properly cited.

\section{INTRODUCTION}

Along with the development of science and technology that occur in Indonesia, all fields of business in Indonesia are also experiencing progress and development. This has caused competition in all fields of business, both transportation, food and beverages, tourism and is no exception in the field of education. The condition of competition in the world of education has begun to be felt by every school by looking at the condition of the community who want their 
children to go to a school that has credibility, quality teaching methods and provides adequate learning facilities. Due to the rapid competition between schools, each school must have superior value to be able to compete with other schools. To face these challenges, leaders need to encourage teachers to empower human resources through developing potential (Malik and Untung, 2013).

Sultan Agung Pematangsiantar Private Middle School is one of the favorite schools in Pematangsiantar City. To be able to compete with Sultan Agung Pematangsiantar Private Middle School, the teacher must improve the performance of the teacher, because teachers have a very strategic role in advancing the success and quality of education. Good performance will get good results, but conversely less good performance will get poor performance results (Komardi and Ayu, 2018). Optimizing teacher performance is one of the concrete steps in building an educational mentality that has been considered less than optimal. Several strategic steps have been taken by the central and regional governments in developing and boosting the performance of teachers in each school in the city, district, sub-district and rural areas.

Performance appraisal related to the implementation of the learning process for teachers includes activities likes planning and assessing, analyzing the results of the assessment and carry out follow-up results of the assessment in applying the 4 competency domains that must be possessed by teachers in accordance with Minister of National Education Regulation Number 16 Year 2007 Regarding Academic
Qualification Standards and Teacher Competency. Learning management requires teachers to master 14 competencies that are grouped into pedagogical, personality, social and professional competencies. The phenomenon of the performance of Sultan Agung Pematangsiantar Private Middle School can be seen from the following table:

Based on table 1 above, it can be seen that the performance of Sultan Agung Pematangsiantar Middle School teacher T.A. 2018/2019 is not optimal yet. This can be seen from the dimensions with an average percentage of $23.75 \%$ and a fairly good response category obtaining an average percentage of $7.5 \%$ for the category of bad answers. The phenomenon of the problem of the performance of Sultan Agung Pematangsintar Private Middle School teachers is seen from personality competence where some teachers often leave the classroom for things that are not important and spend more time on activities that do not support school development. Furthermore, for teacher performance that is not yet optimal, it can be seen from social competence that many Sultan Agung Pematangsiantar Private Middle School teachers uphold a sense of seniority so they feel the most righteous and do not want to accept advice from junior teachers. Based on research (Baumann, 2017), the main focus of school policy lies in increasing school discipline in terms of costs that are neutral, but the impact is very effective on the results to be achieved such as teacher performance and competitiveness.

One factor that is indicated to affect the performance of Sultan Agung Pematangsiantar

Table 1. Phenomenon of Teacher Performance Sultan Agung Pematangsiantar Private Middle School T.A. 2018/2019

\begin{tabular}{lcccccc}
\hline Performance Dimensions & SB & B & CB & TB & STB & Total \\
\hline Pedagogical Competence & $50 \%$ & $25 \%$ & $25 \%$ & - & - & $100 \%$ \\
\hline Personality competence & $25 \%$ & $40 \%$ & $20 \%$ & $15 \%$ & - & $100 \%$ \\
\hline Social Competence & $25 \%$ & $35 \%$ & $25 \%$ & $15 \%$ & - & $100 \%$ \\
\hline Professional Competence & $50 \%$ & $25 \%$ & $25 \%$ & - & - & $100 \%$ \\
\hline Average & $\mathbf{3 7 , 5 \%}$ & $\mathbf{3 1 , 2 5 \%}$ & $\mathbf{2 3 , 7 5 \%}$ & $\mathbf{7 , 5 \%}$ & - & $\mathbf{1 0 0 \%}$ \\
\hline
\end{tabular}

Source: recapitulation of the performance assessment by Sultan Agung Pematangsiantar Middle School teachers (June, 2019) 
Private Middle School teachers is work discipline. Discipline is the most important element for the success of students' academic performance, both inside and outside the school (Njoroge and Ann, 2014). Teacher discipline can be seen from the dimensions of the frequency of attendance, the level of alertness, adherence to work standards, adherence to work regulations and work ethics. The phenomenon of teacher work discipline problems can be seen from the dimension of the frequency of attendance where some teachers are often absent without notice to the school and there are still junior high school teachers who arrive late to school. The phenomenon of teacher work discipline problems can also be seen from the dimension of adherence to work standards where there is still a lack of teacher's awareness to do their work as a teacher so that assignments are often not completed on time. According to Tohardi (2009: 96) states that individual or employee discipline can affect work productivity.

Another factor influencing the performance of Sultan Agung Pematangsiantar Middle School teachers is work ethic. According to Sinamo (2016: 23) states that if the work ethic is exhibited in earnest while working, it also strengthens our confidence in the truth of what is taught as well as in our capacity as evidenced by the increased performance and results we obtain. The work ethic of Sultan Agung Pematangsiantar Middle School teachers can be seen from the dimensions of teacher training, grace, teacher training, teaching is calling, teacher training is actualization, teacher training is worship, teacher training is art, teacher training is honor and teacher training is service. The work ethic in the teaching profession is not just an added value for a student's education but part of a teacher's obligations based on the educational process (Turk and Bojana, 2016).

The phenomenon of the work ethic problem of Sultan Agung Pematangsiantar Private Middle School teachers can be seen from the teacher dimension is grace where there are still Sultan Agung Pematangsiantar Private Middle School teachers who are less responsible in carrying out their duties as a teacher, many tasks are not completed in a timely manner. The phenomenon of the work ethic problem of Sultan Agung Pematangsiantar Private Middle School teachers can also be seen from the teacher dimension is a call where there are still Sultan Agung Pematangsiantar Private Middle School teachers who have not worked with full integrity for the progress of the school. Sultan Agung Pematangsiantar Private Middle School teacher only carries out his/her job if given the appropriate reward according to him $\backslash$ her.

The main objectives of this research study are to analyze: (1) the effect of the quality of work discipline on teacher performance; (2) the effect of the teacher's work ethic on teacher performance; (3) the effect of work discipline and work ethic on teacher performance simultaneously. This research is expected to be able to contribute to Sultan Agung Pematangsiantar Private Middle School in optimizing the performance of his/her teacher as an effort to improve the quality of education in Pematangsiantar and National Cities.

\section{LITERATURE REVIEW Work Discipline}

Discipline is a management action to encourage employees to comply with various requirements in other words, employee discipline is a form of training that seeks to improve and shape knowledge of the attitudes and behaviors of employees so that the employee voluntarily cooperates with other employees to improve work performance. The intensive implementation of discipline directly impacts on performance improvement (Sofyan, et. Al., 2016). According to Rivai (2011: 825), "work discipline is a tool used by managers to communicate with employees so that they are willing to change a behavior and as an effort to increase one's awareness and willingness to meet all company regulations". Furthermore according to Handoko (2003: 208), "work discipline is a management activity to carry out organizational standards". Meanwhile, according to Singodimedjo (2002: 86), "work discipline is an attitude of willingness and 
willingness to obey and obey the norms of regulations that apply in the surroundings". In accordance with the opinion of Sastrohadiwiryo (2005), there are several causes that are suspected to affect work discipline, namely: the frequency of attendance, the level of alertness, adherence to work standards, adherence to work regulations, and work ethics.

\section{Work Ethic}

One must have a view and attitude to respect work as something noble for human existence. Views and attitudes towards work are known as work ethics. According to Anoraga (2009: 282), "the work ethic is a view and attitude of a nation or people towards work." According to Sinamo (2005: 282), "the work ethic is a set of positive behaviors rooted in fundamental beliefs accompanied by a total commitment to the work paradigm the integral. "According to Asifudin (2004: 26)," work ethic is a special trait about an individual or group of people who have attitudes and character, habits and beliefs. "In the perspective of education, there are several indicators related to the work ethic of teacher training namely, teacher training is a blessing, teacher training is a mandate, teacher training is a calling, teacher training is actualization, teacher training is worship, teacher training is an art, teacher training is honor, teacher training is service (Sinamo, 2016).

\section{Teacher Performance}

Performance is not an individual characteristic such as talent or ability but is an embodiment of the talent or ability itself. The ability and expertise possessed by each human resource is the key to the success of a company or organization in developing its vision and mission. Performance is the flow in maximizing goal orientation which is directed to ensure that the processes in the organization are in place to maximize the productivity of employees, teams and ultimately the organization (Mondy, 2008). According to Mathis and John (2006: 113), "performance is the result of work achieved by someone in carrying out the tasks assigned to them based on experience, sincerity and skill and time". According to Rivai
(2004: 309), "performance is a real behavior that is displayed every person as a work achievement produced by employees in accordance with their role in the company". Based on the regulation of the Minister of National Education Number 16 Year 2007 Concerning Academic Qualification Standards and Teacher Competencies, the teacher performance appraisal mechanism includes: pedagogical competence, personality competence, social competence and professional competence.

\section{Effect of Work Discipline on Teacher Performance}

Discipline is part of the most important operational functions of human resource management. The low discipline of teacher work can result in poor quality of education in schools (Nugraheni and Ratna, 2106). The better the discipline of the teacher, the higher the work performance he can achieve. Without good teacher discipline, it is difficult for organizations or agencies to achieve optimal results Good discipline reflects the amount of responsibility someone has for the tasks assigned to him. This encourages enthusiasm for work, enthusiasm for work and improves employee performance and the realization of company or organizational goals.

Based on the results of Jeffrey and Ruliyanto's study (2017); Wahyudi, Partono, and Rediana (2016); Nugraheni and Ratna (2016); Hartono and Zubaidah (2017), Yusuf and Gita (2018), Sya'roni, Toni and Dwi (2018), Supeno, Iman and Ira (2017), explained that work discipline has a positive contribution to teacher performance. In line with the above research, several studies also revealed the same thing about the impact of work discipline on teacher performance such as research conducted by Yudistiro (2015); Soelton (2018); Purwoko (2018); Rosidin and Teguh (2018), Jeffrey and Ruliyanto (2017), revealed that work discipline has a positive impact on teacher performance.

\section{The Effect of Work Ethic on Teacher Performance}

Teaching ethics is a typical intensity that becomes 
the vitality of work, the joy of the heart which becomes the spirit of work and the inner passion that becomes the work stamina of a teacher in carrying out his duties. In addition, charisma which is a personal light of our authority will also be stronger with the development of work ethic. Personality and work behavior that are rooted in noble morality in the ethos of teacher training will emanate through our everyday nature. Work ethics refers to moral behavior in seeing work as a desired activity rather than a burden. Individuals who work with a strong work ethic are very committed to their work and are more satisfied at work (Abbasi and Ghulam, 2012).

In accordance with the results of the Segantara study, I Made and I Gusti (2017); Herminingsih and Widienti (2017); Muslim (2018); Bawelle and Jantje (2016); Karauwan, Victor and Christoffel (2015), Putra, I Made and Nyoman (2017), obtained results about the work ethic having a positive contribution to performance. Based on research by Timbuleng and Jacky (2015); Yantika, Toni and Yusron (2018); Sayuti (2018), Sagay, Bernhard and Greis (2018), Priansa and Agus (2015), Nafiah, Zainul and Noer (2018, Desky (2014), Dwiningwarni and Prince (2017), revealed that the work ethic has a positive impact on performance improvement.

Based on the background described above, the authors describe the conceptual framework as follows:

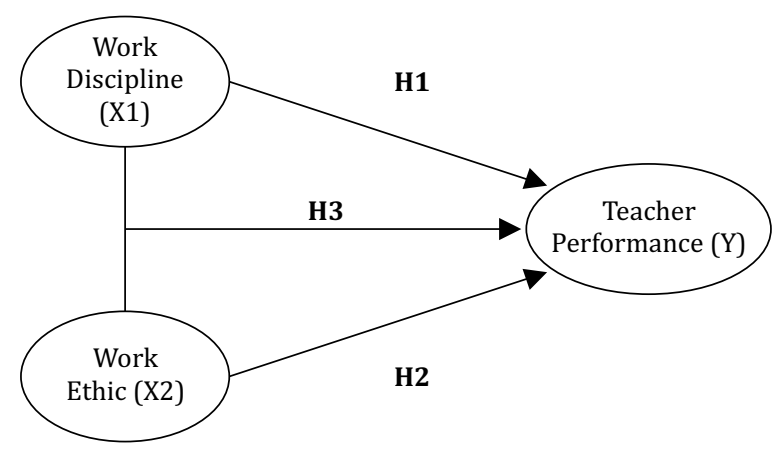

Figure 1. Conceptual Model (Source: Researcher, 2019)

Based on the conceptual framework described above, the authors formulate the research hypothesis as follows:

$\mathbf{H}_{1}$ : Work discipline contributes positively to teacher performance

$\mathbf{H}_{2}$ : Work ethic contributes positively to teacher performance

$\mathbf{H}_{3}$ : Work discipline and work ethic contribute positively to teacher performance simultaneously

\section{RESEARCH METHODS}

This research uses observation and interview methods with quantitative approach models. The location of the study was conducted at Sultan Agung Private Middle School which is located at 19thSurabaya st, Dwikora Village, Siantar Barat District, Pematangsiantar City. Data collection was carried out using a questionnaire instrument that was distributed to respondents manually. The target population is the entire Sultan Agung Pematangsiantar Private Middle School T.A. $2018 / 2019$ of 31 peoples. The sampling technique is done by census method, where the total population is sampled as many as 31 teachers. The analytical tool used in the study used IBM SPSS version 21 statistical software.

Indicator questions contained in the questionnaire consisted of several question items based on research variables namely work discipline, work ethic and teacher performance. The operational definition of variables for work discipline variables includes the frequency of attendance consisting of six indicators, the level of alertness consists of three indicators, adherence to work standards consists of three indicators of compliance with work regulations consisting of three indicators, work ethics consists of four indicators. Next to the work ethic variable includes teacher training is a mercy consisting of six indicators, teacher training is a mandate consisting of three indicators, teacher training is a call consisting of three indicators, teacher training is actualization consisting of four indicators, teacher training is worship consisting of three indicators, teacher training is an art consisting of the three indicators, teacher training is an honor consisting of three indicators, teacher training is service consisting of three indicators. Then for teacher performance variables include pedagogical 
competence consisting of 7 indicators, personality competence consists of 3 indicators, social competence consists of 2 indicators, professional competence consists of two indicators. The weight measurement for each item of variable questions uses a Likert scale, which is 1 = Very Not Good, 2 = Not Good, 3 = Medium /, 4 = Good, 5 = Very Good.

\section{RESULTS AND DISCUSSION}

\section{Description of Respondents}

The description of the respondent's description is part of the explanation of the respondent's profile which is used as the population and research sample. In order not to be biased and representative, the authors divide some of the respondents based on demographics. To find out the general situation of teachers who were used as respondents in this study, the authors made a recapitulation of respondent data presented in the following data tabulations:

Table 2. Description of Respondents by Gender

\begin{tabular}{clcc}
\hline No & Gender & Frequency (f) & Percentage (\%) \\
\hline 1 & Man & 13 & $41,94 \%$ \\
\hline 2 & Woman & 18 & $58,06 \%$ \\
\hline & Total & $\mathbf{3 1}$ & $\mathbf{1 0 0 \%}$ \\
\hline
\end{tabular}

Source: results of data processing (2019)
Table 3. Description of Respondents by Age

\begin{tabular}{clcc}
\hline No & Age (years) & Frequency (f) & Percentage (\%) \\
\hline 1 & $21-30$ years & 3 & $9,68 \%$ \\
\hline 2 & $31-40$ years & 12 & $38,71 \%$ \\
\hline 3 & $41-50$ years & 8 & $25,81 \%$ \\
\hline 4 & $51-60$ years & 6 & $19,35 \%$ \\
\hline 5 & $>61$ years & 2 & $6,45 \%$ \\
\hline & Total & $\mathbf{3 1}$ & $\mathbf{1 0 0} \%$ \\
\hline
\end{tabular}

Source: results of data processing (2019)

Table 4. Description of Respondents Based on Religion

\begin{tabular}{clcc}
\hline No & Religion & Frequency (f) & Percentage (\%) \\
\hline 1 & Islam & 13 & $41,94 \%$ \\
\hline 2 & Christian Protestant & 13 & $41,94 \%$ \\
\hline 3 & Catholic Christianity & 2 & $6,45 \%$ \\
\hline 4 & Hindu & 0 & $0 \%$ \\
\hline 5 & Buddha & 3 & $9,67 \%$ \\
\hline & Total & $\mathbf{3 1}$ & $\mathbf{1 0 0 \%}$ \\
\hline
\end{tabular}

Source: results of data processing (2019)

Validity and Reliability Test

Table 5. Validity and Reliability Test

\begin{tabular}{llcccc}
\hline Research & $\begin{array}{l}\text { Average } \\
\text { value }\end{array}$ & Status & $\begin{array}{c}\text { Average } \\
\text { value }\end{array}$ & Status \\
\hline 1 & Work Discipline & 0,504 & Valid & 0,973 & Reliable \\
\hline 2 & Work ethic & 0,590 & Valid & 0,964 & Reliable \\
\hline 3 & $\begin{array}{l}\text { Teacher } \\
\text { Performance }\end{array}$ & 0,603 & Valid & 0,983 & Reliable \\
\hline
\end{tabular}

Source: results of data processing (2019)

Table 6. Results of the Normality Test

\begin{tabular}{|c|c|c|c|c|c|}
\hline & & Disiplin Kerja & Work ethic & Teacher Performance & Total \\
\hline \multicolumn{2}{|c|}{ Work Discipline } & 31 & 31 & 31 & 31 \\
\hline & Mean & 76,16 & 110,29 & 300,29 & 486,74 \\
\hline \multicolumn{6}{|l|}{ Normal Parameters ${ }^{\mathrm{a}, \mathrm{b}}$} \\
\hline & Std. Deviation & 8,391 & 17,600 & 35,908 & 55,059 \\
\hline \multirow{3}{*}{ Normal Parameters ${ }^{\mathrm{a}, \mathrm{b}}$} & Absolute &, 122 & 113 & 067 &, 079 \\
\hline & Positive &, 082 & ,063 & 045 & ,055 \\
\hline & Negative &,- 122 &,- 113 &,- 067 &,- 079 \\
\hline \multicolumn{2}{|c|}{ Asymp. Sig. (2-tailed) } & ,742 & ,820 & 999 & ,990 \\
\hline
\end{tabular}

a. Test Distribution is Normal.

b. Calculated from data.

Source: results of data processing (2019) 


\section{Normality Test}

Based on Table 5. Kolmogorov one sample normality test above can be seen Asmp. Sig (2tailed) at a total of $\mathrm{X} 1$ (work discipline) of 0.742 , total X2 (work ethic) of 0.820 and total $\mathrm{Y}$ (performance) of 0.999 . And the overall total of 0.990 has asmp. Sig (2-tailed) is greater than alpha 0.05 . Thus, it can be stated that the data from each variable is normally distributed.

\section{Multiple Regression Analysis}

Table 7. Validity Test Results

\begin{tabular}{|c|c|c|c|c|}
\hline & \multirow[t]{2}{*}{ Model } & \multicolumn{2}{|c|}{$\begin{array}{l}\text { Unstandardized } \\
\text { Coefficients }\end{array}$} & \multirow{2}{*}{$\begin{array}{c}\begin{array}{c}\text { Standardized } \\
\text { Coefficients }\end{array} \\
\text { Beta }\end{array}$} \\
\hline & & $\boldsymbol{B}$ & Std. Error & \\
\hline & (Constant) & 78,996 & 43,707 & Beta \\
\hline \multirow[t]{2}{*}{1} & Work Discipline & 1,762 & ,705 & ,412 \\
\hline & Work Ethic & 790 & ,336 & ,387 \\
\hline
\end{tabular}

a. Dependent Variable: Teacher performance

Source: results of data processing (2019)

Based on the results of data processing in table 7 above, the equation model $\hat{Y}=78.996+1,762 \mathrm{X} 1$ $+0.790 \mathrm{X} 2$ is obtained, meaning that there is a positive influence between work discipline and work ethic on the performance of Sultan Agung Pematangsiantar Private Middle School. Following is an explanation of the multiple regression equation above:

- 78.996, meaning that if the work discipline and the work ethic are zero, the teacher's performance is worth 78.996 .

- 1,762, meaning that if work discipline increases by one unit assuming other variables are constant, then teacher performance will increase by 1,762 .

- 0.790 , meaning that if the work ethic rises by one unit assuming other variables are constant, then the teacher's performance will increase by 0.790 .

\section{Correlation Analysis and Determination Coefficient}

Based on the results of the correlation in the table above, obtained a correlation of $r$ value of 0.714 , meaning that there is a strong relationship between the variables of work discipline and work ethic on teacher performance. Then the coefficient of determination is obtained that is 0.474, meaning that good or bad teacher performance is explained by $47.4 \%$ by work discipline and rest of the work ethic is $52.6 \%$ explained by other factors such as l eadership, school principal supervision, teacher competence, communication and teacher professionalism that is not discussed in this study.

\section{Simultaneous Test (F Test)}

From table 9 above the Fcount is 14.520> Ftable at the 0,05 level, ( 2 vs $31-2-1=28$ ) is 3,34 . Because Fcount $>$ Ftable or significance level $0,000<$ from alpha 0,05 , then $\mathrm{H} 0$ is rejected, meaning that work discipline and work ethic have a significant effect on the performance of Sultan Agung Pematangsiantar Private Middle School.

Table 8. Correlation and Determination Coefficients Results

\begin{tabular}{|c|c|c|c|c|}
\hline Model & R & R Square & Adjusted R Square & Std. Error of the Estimate \\
\hline 1 & $.714^{\mathrm{a}}$ & .509 & .474 & 26,042 \\
\hline
\end{tabular}

a. Predictors: (Constant), Work Discipline, Work Ethic

b. Dependent Variable: Teacher Performance

Source: results of data processing (2019)

Table 9. Estimated Results of the Calculated $\mathrm{F}_{\text {Value }}$

\begin{tabular}{|c|c|c|c|c|c|c|}
\hline & Model & Sum of Squares & $D f$ & Mean Square & $\boldsymbol{F}$ & Sig. \\
\hline & Regression & 19693,904 & 2 & 9846,952 & 14,520 & $.000^{\mathrm{b}}$ \\
\hline 1 & Residual & 18988,484 & 28 & 678,160 & & \\
\hline & Total & 38682,387 & 30 & & & \\
\hline
\end{tabular}

a. Dependent Variable: Teacher Performance

b. Predictors: (Constant), Work Discipline, Work Ethic

Source: results of data processing (2019) 


\section{Partial Test (T test)}

Table 10. Estimated Results of the calculated $t_{\text {value }}$

\begin{tabular}{ccc}
\hline Model & t & Sig. \\
\hline (Constant) & & .081 \\
\hline Work Discipline & 2,498 & .019 \\
\hline Work ethic & 2,349 & .026 \\
\hline
\end{tabular}

a. Dependent Variable: Teacher Performance

Source: results of data processing (2019)

From the above table on the work discipline variables obtained tcount of 2,498> ttable with the provisions of $n-k-1$ at an error level of $5 \%$ or $0,05(31-2-1=28)$ of 2,048 or a significant level of 0,019 <of alpha 0,05 then $\mathrm{H} 0$ is rejected, meaning that work discipline has a significant effect on the performance of Sultan Agung Pematangsiantar Private MiddleSchool. Work ethic obtained tcount $2,349>$ ttable with the provisions of $n-k-1$ at the error level of $5 \%$ or $0,05(31-2-1=28)$ of 2,048 or 0,026 significant level <of alpha 0,05 then $\mathrm{HO}$ is rejected, meaning work ethic has a significant effect on the performance of Sultan Agung Pematangsiantar Middle School teachers.

\section{CONCLUSIONS AND RECOMMENDATION Conclusion}

1. There is a positive influence between work discipline and work ethic on teacher performance at Sultan Agung Pematangsiantar Private Middle School.

2. There is a strong relationship between work discipline and work ethic on teacher performance at Sultan Agung Pematangsiantar Private Middle School. Whether or not the performance of teachers in Sultan Agung Pematangsiantar Private Middle School is explained by work discipline and work ethics while the rest is influenced by other factors such as leadership, supervision of the principal, teacher competence, communication and teacher professionalism that are not discussed in this study.

3. The results of simultaneous hypothesis testing with the $\mathrm{F}$ test, obtained by $\mathrm{H} 0$ were rejected, meaning that there was a significant influence between the variables of work discipline and work ethic on the performance of Sultan Agung Pematangsiantar Private Middle School.
4. Partial hypothesis testing results with $t$ test, obtained by $\mathrm{H} 0$ rejected, meaning that there is a significant influence between work discipline and work ethic on the work of Sultan Agung Pematangsiantar Private Middle School partially.

\section{Recommendation}

1. To improve work discipline at Sultan Agung Pematangsiantar Private Middle School, there needs to be a transparent system in recruiting permanent teachers who only teach at Sultan Agung Pematangsiantar Private Middle School so that the teacher focuses on their work. In addition, there is a need for assertiveness from the school principal in overseeing the discipline of teachers regarding their performance.

2. To improve the work ethic of Sultan Agung Pematangsiantar Private Middle School teachers, it is better for the principal as the leader to provide personal and organizational motivation so that every teacher who works can maintain a balanced work ethic competently.

3. To improve the performance of teachers at Sultan Agung Pematangsiantar Private Middle School, it is expected that Sultan Agung Pematangsiantar Private Middle School will further explore and inspire every character, talent and self-potential so that selfactualization to work professionally can be improved.

\section{RESEARCH LIMITATIONS}

In connection with the limitations that exist in the author, this study is still far from perfection and there are still weaknesses and have not been able to reveal all the variables that affect the performance of teachers in Sultan Agung Pematangsiantar Private Middle School and as input for further research need to multiply variables such as leadership, supervision of school principals, teacher competence, communication and teacher professionalism are not discussed in this study. 


\section{RE F ERE N C ES}

Abbasi, Abdus Sattar \& Ghulam Mustafa Mir. 2012. Impact of Teacher's Ability, Student's Work Ethics and Institutional Environment on Student Performance of University of Gujrat. Middle-East Journal of Scientific Research, 12(4), 572-579.

Anoraga, Panji. (2009). Manajemen Bisnis. Semarang: PT Rineka Cipta.

Asifudin, Ahmad Janan. (2004). Etos Kerja Islami. Yogyakarta: Muhammadiyah University Press.

Baumann, Hana Krskova Chris. (2017). School Discipline, Investment, Competitiveness and Mediating Educational Perfomance. International Journal of Education Management, 31(3), 1-49.

Bawelle, Mouren \& Jantje Sepang. (2016). Pengaruh Etos Kerja, Gairah Kerja dan Disiplin Kera Terhadap Kinerja Karyawan PT BRI Cabang Tahuna. Jurnal EMBA, 4(5), 353-361.

Desky, Harjoni. (2014). Pengaruh Etos Kerja Islami dan Gaya Kepemimpinan Terhadap Kinera Karyawan Rumah Makan Ayam Lepaas Lhokseumawe. INFERENSI: Jurnal Penelitian Sosial Keagamaan, $8(2), 459-478$.

Dwiningwarni, Sayekti Suindyah \& Prince Dindah. (2017). Pengaruh Budaya Organisasi Dengan Pendekatan Integritas, Etos dan Lingkungan Kerja Terhadap Kinerja Organisasi. Jurnal EKSIS, 12(2), 149-160.

Handoko, T. Hani. (2003). Manajemen Sumber Daya Manusia. Yogyakarta: Bumi Aksara

Hartono, Bambang Dwi \& Zubaidah. (2017). The Influence of Leadership, Organizational Culture and Work Discipline on Teacher Perfomance Regarding Work Motivation as Intervening Variable (A Case Study of Yayasan Pendidikan Pondok Pesantren Al Kholidin). International Journal Economics, Business and Management Research, 1(1),69-95.

Herminingsih, Anik \& Widienti Supardi. (2017). The Effect of Work Ethics, Transformational and Transactional Leadership on Work Perfomance of Teachers. Management Studies, 5(3), 250-261.

Jeffrey, Ignatius \& Ruliyanto. (2017). The Effect of Competence, Training and Work Discipline towards Employees' Performance (A Case Study at PT. Krakatau Argo Logistics). International Journal of Business and Management Invention, 6(7), 77-86.

Karauwan, Raynald, Victors P.K. Lenkong \& Christoffel Mintardjo. (2015). Pengaruh Etos Kerja, Budaya Organisasi dan Beban Kerja Terhadap Kinerja Pegawai Di Dinas Pekerjaan Umum Minahasa Selatan. Jurnal EMBA, 3(3), 1196-1207.

Komardi, Dadi \& Ayu Sri Ningsih. (2018). Pengaruh Disiplin Kerja dan Motivasi Kerja Terhadap Kinerja Guru SMA Muhammadiyah 1 Pekanbaru. Jurnal KURS, 3(1), 56-66.

Malik, Abdul \& Untung Sriwidodo. (2013). Pengaruh Motivasi Kerja dan Kedisiplinan Terhadap Kinerja Guru SMA Assalaam Surakarta Dengan Kepemimpinan Kepala Sekolah Sebagai Variabel Moderasi. Jurnal Sumber Daya Manusia, 7(1), 53-66.

Muslim, Septiana. (2018). Pengaruh Etos Kerja, Kompensasi dan Kedisiplinan Terhadap Kinerja Karyawan di Fakultas Keguruan dan Ilmu Pendidikan (FKIP) Universitas Sarjanawiyata Tamansiswa Yogyakarta. Jurnal Ekobis Dewantara,1(2),123-128.

Nafiah, Umi Lailatun, Zainul Hidayat \& Noer Aisyah Barlian. (2018). Pengaruh Etos Kerja dan Disiplin Kerja Terhadap Kinerja Perawat Pada Puskesmas Labruk Kidul Kecamatan Sumbersuko Kabupaten Lumajang. Jurnal Riset Manajemen, 1(2), 143-154.

Njoroge, Philomena Mukami \& Ann Nduku Nyabuto. (2014). Discipline as a factor in Academic Perfomance in Kenya. Journal of Educational and Social Research, 4(1), 289-307.

Nugraheni, Aninditya Sri \& Ratna Rahmayanti. (2016). Pengaruh Disiplin Kerja Terhadap Kinerja Guru di MI AI Islam Tempel dan MI Al Ihsan Medari. Jurnal Pendidikan Madrasah,1(2),277-293.

Peraturan Menteri Pendidikan Nasional Nomor 16 Tahun 2007 Tentang Standar Kualifikasi Akademik dan Kompetensi Guru.

Priansa, Donni Juni \& Agus Garnida. (2015). Pengaruh Kepemimpinan Visioner dan Etos Kerja Terhadap Kinerja Pegawai Bank Syariah Mandiri. Jurnal Ecodemica, 3(1), 342-347. 
Putra, Cok Agus Ady, Made Yudana \& Nyoman Natajaya. (2017). Hubungan Motivasi Berprestasi, Perilaku Kepemimpinan Kepala Sekolah dan Etos Kerja Dengan Kriteria Guru. Jurnal Penelitian dan Pengembangan Sains dan Humaniora, 1(1), 14-20.

Purwoko, Sidik. (2018). Pengaruh Kepemimpinan Kepala Sekolah, Komitmen Guru, Disiplin Kerja, dan Budaya Sekolah Terhadap Kinerja Guru SMK. Jurnal Akuntabilitas Manajemen Pendidikan, 6(2), 149-162.

Rivai, Veithzal. (2009). Manajemen Sumber Daya Manusia. Jakarta: PT Raja Grafindo.

Rosidin, Farhan Hakim \& Teguh Widodo. (2018). Pengaruh Motivasi Berprestasi dan Disiplin Kerja Terhadap Kinerja Guru (Studi Kasus Pada Sekolah Menengah Pertama Negeri di Kecamatan Bekasi Timur). E-Proceeding of Management, 5(2),1917-1924.

Sagay, Imanuel Frans, Bernhard Tewal \& Greis Sendow. (2018). Pengaruh Iklim Organisasi, Lingkungan Kerja Fisik dan Etos Kerja Terhadap Kinerja Karyawan PT Pelabuhan Indonesia IV (Persero) Terminal Petikemas Bitung. Jurnal EMBA, 6(3), 1708-1717.

Sastrohadiwiryo, H.B. Siswanto. (2005). Manajemen Tenaga Kerja Indonesia Pendekatan Adminitrasi dan Operasional. Jakarta: Bumi Aksara.

Sayuti. (2018). Pengaruh Kepemimpinan, Motivasi dan Etos Kerja Terhadap Kinerja Pegawai Balai Pemasyarakatan (BAPAS) Kelas 1 Banjarmasin. Jurnal Imiah Ekonomi Bisnis, 4(2), 275-287.

Segantara, I Gede Mahendra, I Made Yudana \& I Gusti Ketut Arya Sunu. (2017). Studi Korelasi Antara Motivasi Kerja, Kompetensi Profesional Guru, dan Etos Kerja Terhadap Kinerja Guru. Jurnal Penelitian dan Pengembangan Sains dan Humaniora, 1(1), 29-34.

Sinamo, Jansen. (2005). Etos Kerja Profesional. Jakarta: PT Spirit Mahardika.

Sinamo, Jansen. (2016). 8 Etos Kerja Keguruan. Jakarta: Erlangga.

Siregar, Fauziyah Novia Khoirunnisa \& Partono Thomas. (2015). Pengaruh Disiplin Kerja dan Iklim Kerja Terhadap Kinerja Guru Ekonomi/Akuntansi di SMA Negeri Se-Kabupaten Wonosobo. Economic Education Analysis Journal, 4(1), 172-177.

Soelton, Mochamad. (2018). How Culture, Training Standard and Discipline on the Employee Perfomance Affect Hotel Management. European Research Studies Journal, 21(4),378-385.

Sofyan, Muhammad, et. al. (2016). The Effect Of Career Development and Working Discipline Towards Working Satisfaction and Employee Perfomance In The Regional Office of Ministry of Religious Affairs In South Sulawesi. International Journal of Scientific \& Technology Research, 5(3), 51-57.

Supeno, Imam Suseno \& Ira Miranti. (2017). Pengaruh Motivasi, Disiplin Kerja dan Gaya Kepemimpinan Kepala Sekolah Terhadap Kinerja Guru Bahasa Inggris SMP DKI Jakarta. Jurnal DEIKSIS, 9(1), 90-99.

Sya'roni, Toni Herlambang \& Dwi Cahyono. (2018). Dampak Motivasi, Disiplin Kerja dan Kepemimpinan Kepala Sekolah Terhadap Kinerja Guru. Jurnal Sains Manajemen dan Bisnis Indonesia, 8(2), 131-147.

Timbuleng, Stela \& Jacky S. B. Sumarauw. (2015). Etos Kerja, Disiplin Kerja dan Komitmen Organisasi Pengaruhnya Terhadap Kinerja Karyawan Pada PT Hasjrat Abadi Cabang Manado. Jurnal EMBA, 3(2), 1051-1060.

Tohardi, Ahmad. 2008. Pemahaman Praktis Manajemen Sumber Daya Manusia. Bandung, Universitas Tanjung Pura: Mandar Manju.

Turk, Marko \& Bojana Vignjevic. 2016. Teachers' Work Ethic: Croatian Students' Perpective. Foro de Education, 14(20), 489-514.

Wahyudi, Adi, Partono Thomas \& Rediana Setiyani. (2012). Pengaruh Disiplin Kerja, Motivasi Kerja dan Supervisi Kepala Sekolah Terhadap Kinerja Guru. Economic Education Analysis Journal, 1(2), 1-8.

Yantika, Yuli, Toni Herlambang \& Yusron Rozzaid. (2018). Pengaruh Lingkungan Kerja, Etos Kerja dan Disiplin Kerja Terhadap Kinerja Karyawan (Studi Kasus Pada Pemkab Bondowoso). Jurnal Manajemen dan Bisnis Indonesia, 4(2),174-188. 
Darwin Lie, et al. / The Impact of Work Discipline and Work Ethic on the Teacher Performance of Sultan Agung Pematangsiantar Private Middle School Teachers T.A. 2018/2019 / 125 - 135

Yudistiro, Indra Agung. (2015). Pengaruh Kecerdasan Emosional, Lingkungan Kerja dan Disiplin Terhadap Kinerja Guru Dengan Komitmen Organisasi Sebagai Moderasi. Jurnal Manajemen Sumber Daya Manusia, 9(1), 38-50.

Yusuf, Tamzil \& Gita Suci. (2018). Pengaruh Kompetensi Profesional Guru, Motivasi Kerja dan Disiplin Kerja Terhadap Kinerja Guru SMK Negeri 2 Penajam Paser Utara. Jurnal GeoEkonomi, 1(1), 117-131. 